\title{
OBSERVATIONS ON THE NESTING BEHAVIOUR OF THE SAW-WHET OWL IN ALBERTA
}

SANDRA and ANTHONY JOHNS, No. 146 - 1128 McKercher Drive, Saskatoon, Saskatchewan S7H 4 Y7 and G. RAINER A. EBEL, 8016 - 180 Street, Edmonton, Alberta T5T 0T3

In general, relatively little is known about owls, despite their wide distribution and abundance in many areas, as most species are nocturnal and, therefore, difficult to study. The Saw-whet Owl is the second smallest of our western Canadian owls and although widely distributed across extreme southern Canada little information is available in the literature on its nesting behaviour. ${ }^{4}$ Perhaps the best reference to date on the life history of the Saw-whet remains that published by Bent. ${ }^{2}$ More recently a study by Graber detailed food, oxygen and metabolic rate while numerous authors have elaborated on the winter distribution of this tiny owl. ${ }^{5} 136689 \mathrm{~A}$ study of its nesting behaviour in relation to nest boxes was conducted by Santee and Grenfield. ${ }^{10}$ This was the only paper located which was pertinent to our study.

Our study area was somewhat accidentally chosen; by mid-February rumour had it that Saw-whet Owls were calling from a black spruce bog (locally known as the Wagner Property) located approximately 15 miles northwest of Edmonton. On February 18, 1977 we visited the area just after dark and began imitating what we believed to the the territorial call of a Saw-whet. We waited for a response and obtained our first reply at 2230 hours. The owl called as it flew towards us and landed in a small stand of spruce. We tape-recorded this call and then played it back in the vicinity where we thought the owl to be, but without success. Later that evening we managed to locate three separate Sawwhet Owls by using the recorded call; the response, however, was neither consistent nor maintained for any length of time. Spontaneous callings of
Saw-whet Owls in this area were not heard at this time.

Subsequent trips to the Wagner Property during February and March revealed the presence of a single Great Horned Owl and Long-eared Owl, three Boreal Owls and six Saw-whet Owls - all based on their calling. We counted another four Saw-whet Owls calling from various stands of spruce trees within the city limits of Edmonton on March 12.

During March we investigated the Wagner Property during the day in an attempt to find a Saw-whet Owl nest. Every likely tree was tapped and, eventually, on March 27, our diligence paid off. A balsam poplar stump situated close to a road on the edge of the bog was tapped and a Saw-whet Owl flew out, alighting on a tree some 20 feet away. The stump was approximately 16 feet high with two holes 11 and 12 feet from the ground. The owl nested in the lower hole, which was probably occupied the previous summer by a Common Flicker, as several feathers belonging to this species were observed inside the cavity. The stump was on the edge of a small stream running from the south to the north and 50 feet from a gravel road. The major vegetation in the immediate area was willow shrub, balsam poplar and trembling aspen. To the east of this area was a cultivated field which was surrounded on the other three sides by the spruce bog proper. The nest opening faced east towards this cultivated field.

Observations were made on 16 evenings between March 27 and May 18 (53 days) for a total of 25 hours. During this period no pellets were found although a daily intensive 


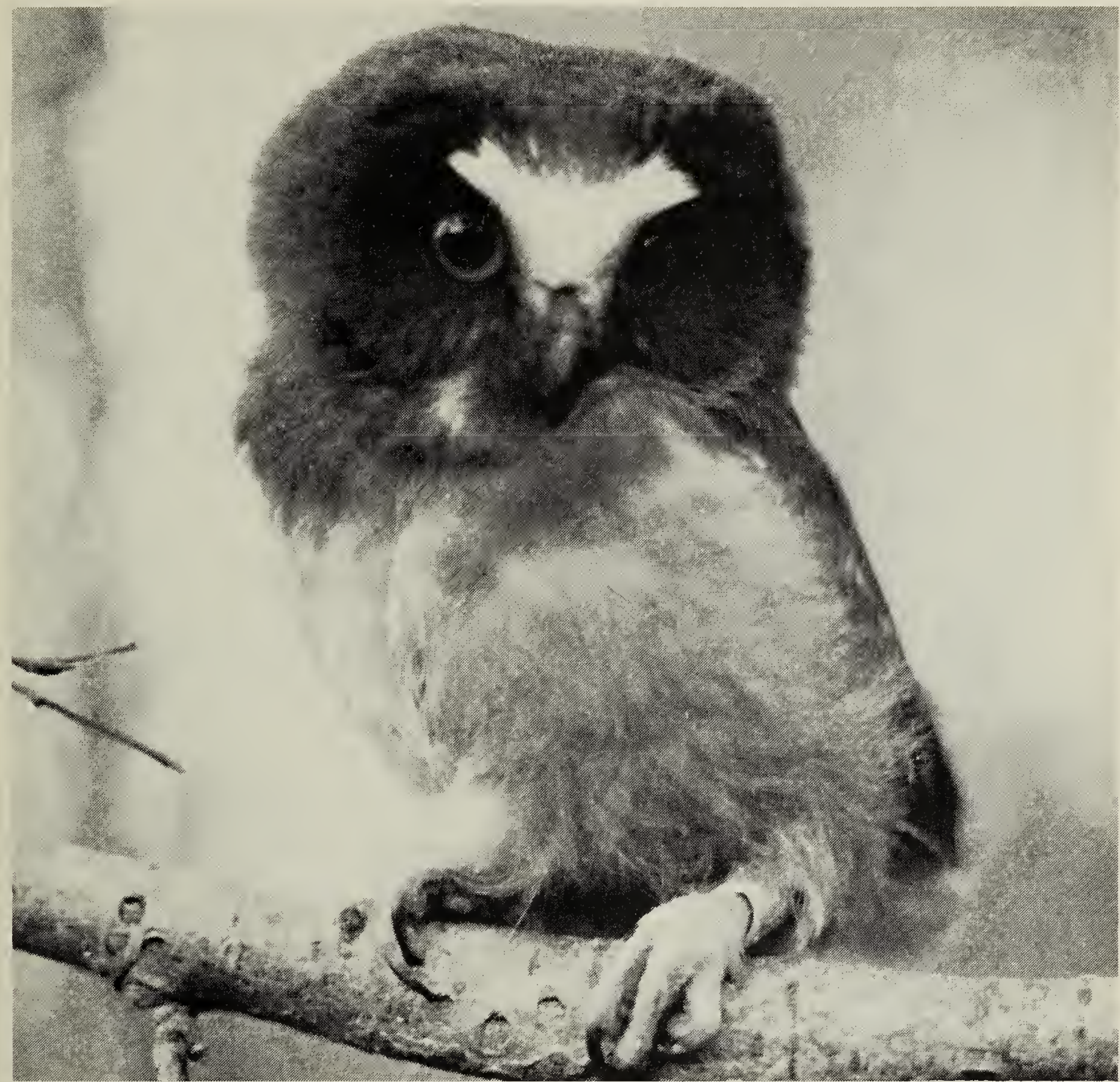

Young Saw-whet Owl

Anthony Johns

search was conducted under the nest stump and under the trees most frequently used for calling by the owl.

Throughout our observations the bird resident in the tree stump was only seen to leave the nest cavity three times (assumed to be the female because the major portion of the incubation is carried out by the female $\left.{ }^{2}{ }^{10}\right)$. The first time she left when the tree was originally discovered; the second was on March 28 when she left 20 minutes after sunset. She called as she flew some distance from the nest but the call was much softer than the normal call of the Saw-whet Owl. Four minutes later two Saw-whet Owls returned; one flew to the nest hole but did not enter, then the second owl flew and entered the cavity. The owl remaining outside started giving a normal Saw-whet Owl call. The female (bird in the nest) also left one evening when we attempted a flash picture of the male owl approaching the nest. Neither owl returned to the nest for 10 minutes, when the same behaviour as mentioned before took place.

After our original discovery of the nest we tried to induce the incubating bird to leave by rapping the tree; however, looking into and even placing a hand into the nest cavity would not make the bird leave. The diameter of the hole was such that an adult human hand (at least ours) could get through only with great difficulty. Therefore, we were unable to deter- 
mine the number of eggs or laying and hatching dates. On May 12, 1977, six young Saw-whet Owls were removed from the nest and banded by R. E. Gehlert who estimated the oldest owl to be about 18 days old. It could glide but not fly and the three largest of the young were able to maintain their balance on a branch, whereas the younger owls had great difficulty in remaining upright. The nest cavity was dirty, smelly, warm and very humid. When the owls were replaced in the nest cavity they rearranged their positions so that the largest owlet was on the top of the others.

We observed some interesting behaviour of the male owl (assumed to be male since it was the nonincubating bird). When feeding the incubating bird or passing food into the nest, he was observed (on three occasions when there was sufficient light) to transfer the food, a small rodent, from his talons to his beak before flying to the nest tree. The male called while flying and carrying the prey in his beak. We were unable to photograph this behaviour. Santee and Grenfield present photographic evidence suggesting the male Sawwhet Owl carries prey to the nest in its talons. We never observed this behaviour. Santee and Grenfield do mention transfer of food from talons to beak when they saw the female fly to feed her young. ${ }^{10}$

The male arrived in the vicinity of the nest tree between 10 minutes to 2 hours after sunset. The time of his arrival bore no obvious correlation to weather or light conditions. On one occasion, when the male arrived 10 minutes after sunset, he attacked an American Robin singing near the nest tree. $^{7}$

During the early period of our observations (before May 12) one owl, presumably the female, was always in the nest cavity. ${ }^{2} 10$ From May 12 on, however, we found only the owlets in the nest cavity, suggesting that at this time the feeding of the young is performed by both owls.

The male owl had two distinct calls, one loud, harsh, territorial call and a second softer call. The territorial call was uttered from different trees within about 30 feet of the nest. The second softer, quieter call, which we named his "visting call," was only heard when the owl was approaching or leaving the nest tree. This differentiation of the male's call is also briefly mentioned by Santee and Grenfield. ${ }^{10}$ On one occasion, however, the male gave the territorial call as he flew to and from the nest.

The incubating bird was also heard calling on the occasion that she voluntarily left the nest. Both the call she made as she left the nest and the call she made from a tree 40-50 feet from the nest were similar to the "visiting call" of the male bird.

We hope to continue our studies on the Saw-whet Owl and would be interested in receiving any observations on the behaviour of this owl from other naturalists.

'AUSTIN, G. R. 1958. The unsuspicious Saw-whet Owl. Audubon Magazine $60: 272-275$.

${ }^{2}$ BENT, A. C. 1938. Life histories of North American birds of prey. Part 2. Dover Publication, New York.

${ }^{3}$ FORBES, J. E., and D. W. WARNER, 1974. Behaviour of radio-tagged Saw-Whet Owl. Auk 91:783-795.

${ }^{4}$ GODFREY, W. E. 1966. The birds of Canada. Bull. 203. Nat. Mus. of Canada. 428 pp.

${ }^{5}$ GRABER, R. R. 1962. Food and oxygen consumption in three species of owls. Condor 64:473-487.

${ }^{6} \mathrm{HOLT}$, J. B. 1959. Counting small owls at night. Audubon Magazine 61:262-265.

7JOHNS, S. 1977. Saw-whet Owl attacks Robin. Blue Jay 35:172.

${ }^{8}$ MULFORD, R. E., and R. L. ZUSI, 1958. Notes on movements, territory and habitat of wintering Saw-whet Owls. Wilson Bull 78:188-191.

${ }^{9}$ RANDLE, W., and G. R. AUSTIN, 1952. Ecological roles on Long-eared and Saw-whet owls in southwestern Ohio. Ecology 33:422-426.

I0SANTEE, R., and W. GRENFIELD, 1939. Behaviour of the Saw-whet owl on its nesting grounds. Condor 41:3-9. 